In 1 edia $\quad \begin{aligned} & \text { InMedia } \\ & \text { The French Journal of Media Studies }\end{aligned}$

8.2. $\mid 2020$

What do Pictures Do? (In)visibilizing the Subaltern

\title{
Neutralizing the Surveillant Gaze: Parades of the Filmic Body
}

\section{Rémi Lauvin}

\section{(2) OpenEdition \\ 1 Journals}

\section{Electronic version}

URL: https://journals.openedition.org/inmedia/2579

DOI: 10.4000/inmedia.2579

ISSN: 2259-4728

\section{Publisher}

Center for Research on the English-Speaking World (CREW)

\section{Electronic reference}

Rémi Lauvin, "Neutralizing the Surveillant Gaze: Parades of the Filmic Body", InMedia [Online], 8.2. I

2020, Online since 22 October 2021, connection on 28 October 2021. URL: http://

journals.openedition.org/inmedia/2579; DOl: https://doi.org/10.4000/inmedia.2579

This text was automatically generated on 28 October 2021.

(c) InMedia 


\title{
Neutralizing the Surveillant Gaze: Parades of the Filmic Body
}

\author{
Rémi Lauvin
}

\section{Hide and Seek: Cinema and the Dialectics of (In)Visibility}

On May $31^{\text {st }}, 2020$, an Instagram user called "Pizzalawyer420" posted a series of images accompanied by text detailing "Pro tips on how to avoid metadata + facial recognition in protest pics." Just a few days after the beginning of violently repressed demonstrations demanding justice for the death of George Floyd, this post circulated among protesters-mostly young, liberal, left-leaning individuals. In this post, it is suggested that the visual deterioration of images is largely inefficient, and that the use of a "clone stamp tool," which "literally adds randomized info to the pic and is much more effective than blurring,", was preferable. This post signals several distinct evolutions in the forms of socio-cultural struggles, and in the transformation of street clashes into a digital, AI-driven phenomenon. It can also help us assess the consequences of the generalization of identification, which casts suspicion on participation in democratically protected rights. Routine facial recognition confronts routine forms of resistance, created by and shared amongst masses of individuals fighting for the preservation of their anonymity.

This post is also revealing of the versatility of social media that are often dismissed as the vector of mindless self-mediatization. The circulation of online, DIY techniques of resistance on Instagram hints at a quasi-redemptive quality, promoting self-erasure rather than self-exposure. In a way that can be compared to the role played by Facebook in the emergence of various uprisings over the past decade, this post illustrates the duplicity of social media, which can offer material for personal identification and future prosecution, while enabling the circulation of tools for covering one's tracks, both on and offline. 
The visibility at stake, here, is not purely optical. It is not offered to the gaze of a human observer, but to the digital process that will scan and identify the components of digital identities. It is constituted of decodable, searchable information or metadata, a set of information which is embedded within digitally formatted objects. ${ }^{1}$ It is not the faces displayed as Instagram profile pictures that are subjected to falsification, but the digital raw material itself.

The Instagram post provides further instructions: "place several layers of emoji over the face - the more digital information you have over the face the harder it will be to remove later." It is unclear whether this technique is efficient or not; but that is not the point here. Rather, this post outlines a strange strategy in the obtention of invisibility, one that is, we can argue, the most emblematic of contemporary image counterfeiting: the generation of emoji, i.e., pictural icons that replace and stand for photographic depictions of facial attitudes and emotions. Here, these icons are used to produce a form of camouflage of the image, a digital thickness that thwarts the recognition of identifying makers in the image. Superposing emojis in order to disrupt identification, overcrowding images with parasitic visual objects: it seems that excessive visibility can ensure anonymity more efficiently than sheer invisibility. This paradox stands at the forefront of reflections on image-making in the digital age.

We argue that this approach, albeit grounded in the present socio-political context, stems from a longer history that involves other, non-digital images. The visual arts, and cinema in particular, have had a distinct role in the makings of resistance gestures against surveillance.

Cinema is twice involved with surveillance. As a technological agent, it provides the instruments of video-based surveillance and anticipates the "caught-on-tape" power of the camera, as Tom Gunning notes. ${ }^{2}$ But it also contributes to a concurrent perspective, by reenacting or inventing bodies that hide, mask, or camouflage themselves. Film archives the way we behave and react towards image-making devices. As such, it can help us answer critical questions regarding the way images trap or liberate us from surveillance: What are the political effects of organized invisibility? What visual experiences have helped invent modes of disappearance? Can such rhetoric be applied beyond a reflection on the politics of (in)visibility? How do the visual arts in general, and cinema in particular, invoke and illustrate historical and political forms of resistance to oppressive visibility, and how do they invent original strategies of invisibilization?

I intend to argue that the invention of invisibility is as essential to cinema as the promotion of visibility that is often central to seminal readings of the history of cinema. Early cinema provides eclectic representations of surveillant and vanishing bodies. Several works will structure our analysis of self-effacement in early film: shorts from the Lumière and Méliès catalogues, Cecil M. Hepworth's 1900 Clown and Police, A.E. Weed's twin films from 1904, Photographing a Female Crook and Subject for the Rogues Gallery. Later films from the 1930s and the 1940s (the 1936 documentary-style and FBI praise piece You Can't Get Away With It; Phil Karlson's 1946 Charlie Chan: Dark Alibi) will help us assess the persistence of a certain fascination for the art of being invisible, or at least unidentifiable. A close analysis of these images is crucial to understanding how cinema negotiates with its own tools to reenact or invent, sometimes from scratch, the spectacle of invisibility. Film analysis enables us to unpack the intricate fantasies that stem from a wide net of influences and crystallize within the filmic image. In this 
perspective, supporting a specific approach to the filmic image is not incompatible with the goal of surveillance studies. Rather, cinema plays a double role regarding surveillance practices: it documents their reality while fantasizing their power as well as their limitations. I argue that these figures generated by cinema play a key role in the depiction of the powers and limitations of surveillance from the late $19^{\text {th }}$ to the early $21^{\text {st }}$ century. In fact, whereas cinema has been largely celebrated as one of the instruments enabling the triumph of vision, this paper provides counterpoints to this theory, by identifying, comparing and classifying the forms of invisibility, unreadability and limits of identification that have been (re)invented through the history of film.

The art of being unseen, I argue, describes an ensemble of figures that are made to appear and then vanish, fooling the scrutinizing gaze of voyeurs, slapstick policemen and, later, facial recognition devices. This invention proceeds from three main strategies: becoming imperceptible, becoming unrecognizable, and becoming undistinguishable from another image by producing a decoy or an artificial double of oneself. Ultimately, I will argue that cinematographic image-making is itself a disappearing act, an art of evanescence just as much as it is an art of apparition. In other terms, I argue that the filmic image, far from the proto-surveillant entity it has often been described $\mathrm{as}^{3}$, can be considered a refuge from the visible realm. It could be argued that the transformation into its filmic double is, in itself, a forgery, and that the filmic image serves a counterfeiting function, which can help us reverse the role of cinema in relation to surveillance strategies-cinema as an accomplice of those who seek to escape from identification, rather than as an agent of detection and revelation.

We use the term "falsification," here, along with "counterfeiting." Both designate the act of constructing, from scratch or using preexisting elements, altered copies of the human face, which is the main target of identification. Counterfeited objects are usually created in order to pass for authentic ones. Falsified ones, on the other hand, often exhibit their alteration. We define falsification as the act of transforming objects into their deteriorated or unreadable doubles. The modes of resistance to identification and surveillance techniques explored here live in a grey area: they specifically evolve in a liminal space, where their recognition cannot be asserted with absolute certainty. We precisely need to use these two terms alternatively, because these camouflage and misidentification techniques navigate both territories: by passing for originals, or by becoming unreadable or undecipherable. In other terms, counterfeiting preserves identification, whereas falsification disrupts it. A counterfeited object passes for an original and simulates authenticity, while a falsified one generates erroneous results to any identification attempt.

\section{Conquering Imperceptibility}

\section{Intermittent Vision: The Flickering Lights of Early Cinema}

Anthropometric measurements and finger print identification were already in widespread use amongst the police by the turn of the $20^{\text {th }}$ century in Europe and in the United States. ${ }^{4}$ After twenty-odd years of experimentation, first in the British colonies, ${ }^{5}$ then in criminal and mental health institutions, ${ }^{6}$ the procedural capture of a photographic portrait, the recording of fingerprints, and the measurements of a dozen 
key dimensions of the body were fully instituted in police stations in Europe, North America, and in overseas colonies. But just as the tools meant for identification got more and more complex, cinema invented imaginary forms of diversion.

Whereas important research has focused on the links between early cinema and the aesthetics of apparition, ${ }^{7}$ we can provide elements for a concurrent theory that would characterize the invention of cinema as an exercise in invisibility. Much has been said already about the filiation between cinema and magic. ${ }^{8}$ Early auteurs were often trickmakers, such as Georges Méliès, Segundo de Chomón, Romeo Bosetti, and Alice Guy. Multiple early films are conducted by characters that dictate the disappearance and the manifestation of objects, animals, or other beings. These figures situate themselves in a liminal space, not exactly fictitious nor external to the fantastic, delirious world they depict; these magician-like operators help lure the spectator into the fascinating world depicted on screen, "willing to rupture a self-enclosed fictional world for a chance to solicit the attention of the spectator." As such, they organize the play on apparition and evanescence like real-time editors of the world in which they live. The fascination described by early observers for what was suddenly revealed by cinema always coexisted with a fascination regarding vanishing acts. Cinema's power to conjure the real goes both ways, back and forth; just as much as it can generate figures, it can draw them back to imperceptibility, and thus, to their absence on-screen. The founding principle of cinema as the art of image-making is thus tightly woven with its twin power, that of image-suppression. The sensible world of cinema has been defined by volatility and impermanence before. ${ }^{10}$ Images and figures appear, but only fleetingly so. The material history of cinema also teaches us, by focusing on the ruin, obsolescence and decay of its primary materials, how precarious the life of film is.

Several films by George Méliès illustrate the attractiveness of image impermanence within fiction. We can observe a certain trend in the way that the act of vanishing is represented, between the mid-1890s and 1899. In 1896-1897, several films depict the chaotic play on apparition and disappearance. Films by Georges Méliès, like A Nightmare (Le cauchemar, 1896, Fig. 1) and The Bewitched Inn (L'auberge ensorcelée, 1897, Fig. 2), depict frenetic, nightmarish environments in which characters suffer from the spontaneous manifestation and evaporation of objects and figures around them (chairs, beds, young women and minstrels, even the moon itself). These films depict a swappable universe where, in the blink of an eye, anything could vanish or be replaced by another thing. The intermittent nature of the cinematic worlds mimics the process of early cinematic imagery in the late $19^{\text {th }}$ century: bodies and objects flicker wildly, with a pace that recalls the hectic, and sometimes straining, flickering of the light in screenings in the 1890s..$^{11}$ At the center of this impermanent world often stands a confused character, on the verge of delirium. We can argue that this character is quite a transparent avatar of the filmic audience. Both this delirious being and the audience members experience a dizzying sensory experience, witnessing the impermanence of a world that flickers before their eyes. 


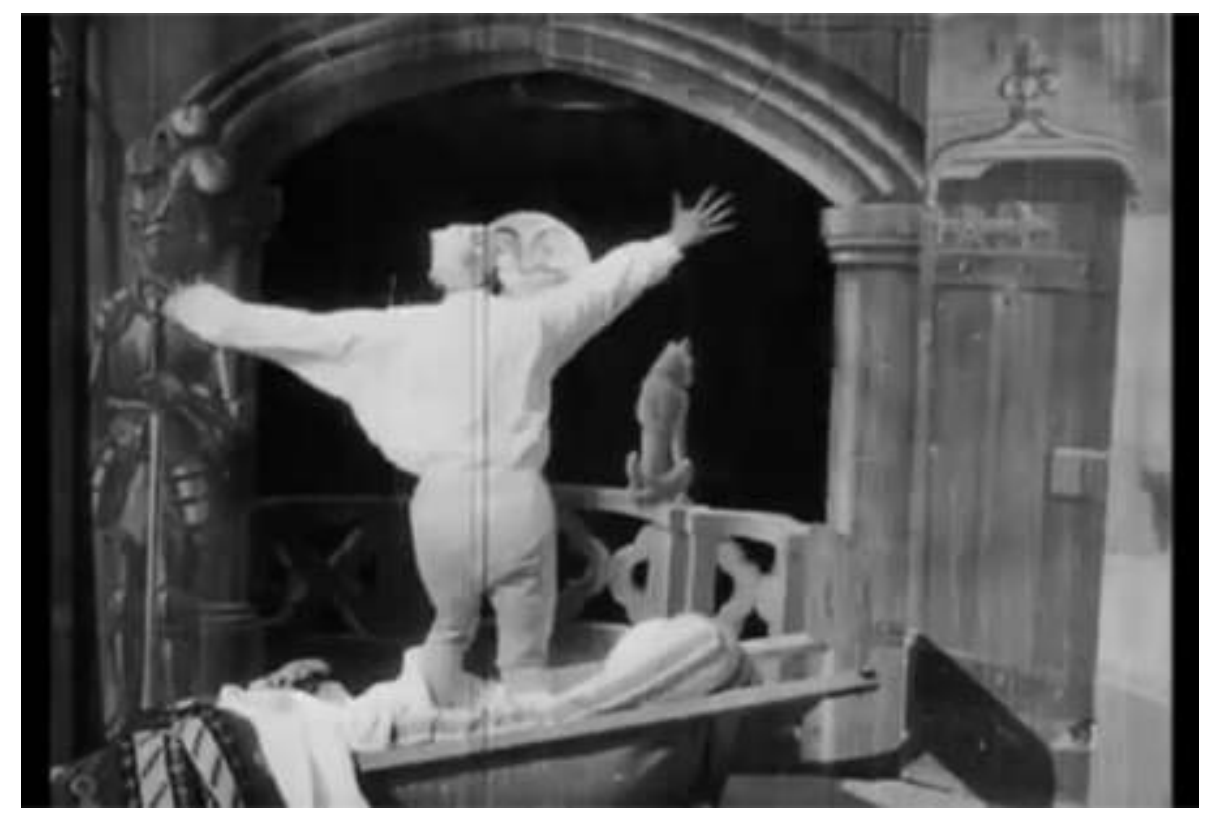

Fig. 1: The Nightmare (Georges Méliès, 1896)

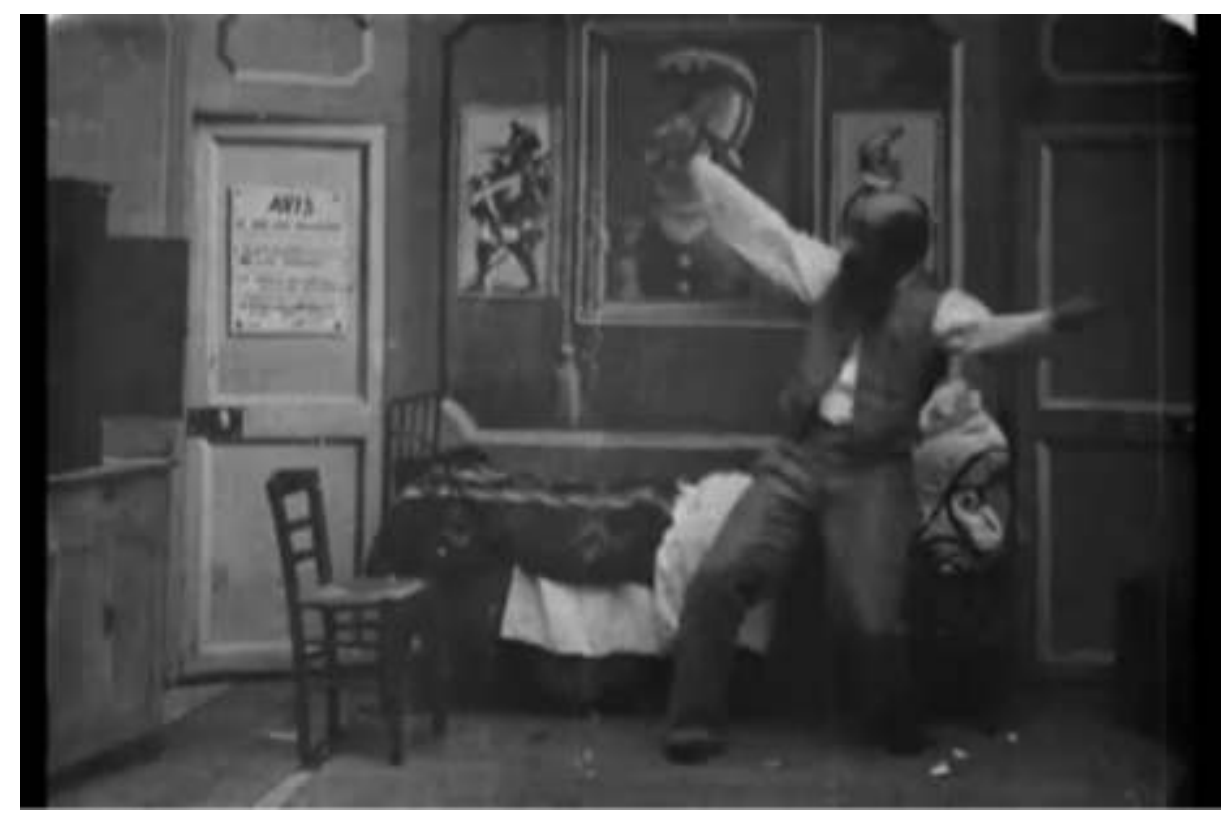

Fig.2: The Bewitched Inn (Georges Méliès, 1897)

Just a few years later, we observe a shift in the depiction of this apparitional and vanishing universe. A single character still stands at its center, but this time, this character directs and organizes the materialization and the disappearance of the world around him. He is not a victim of his flickering environment anymore. Méliès plays the role of this magician figure himself in A Mysterious Portrait (Le Portrait Mystérieux, 1899, Fig. 3) and Summoning the Spirits (Evocation spirite, 1899, Fig. 4). In both cases, the power to generate, give life to, and dismiss portraits is constructed by delineating a frame, a surface within which images can appear. These conjurors work with images only, not bodies or three-dimensional objects: their powers are strictly located within circular or rectangular portrait frames. Taming (in)visibility, here, is 
associated with the framing of the visible. The skill of the image-maker (managing apparition and evanescence) mirrors that of the filmmaker, in the sense that it works within a delineated frame.

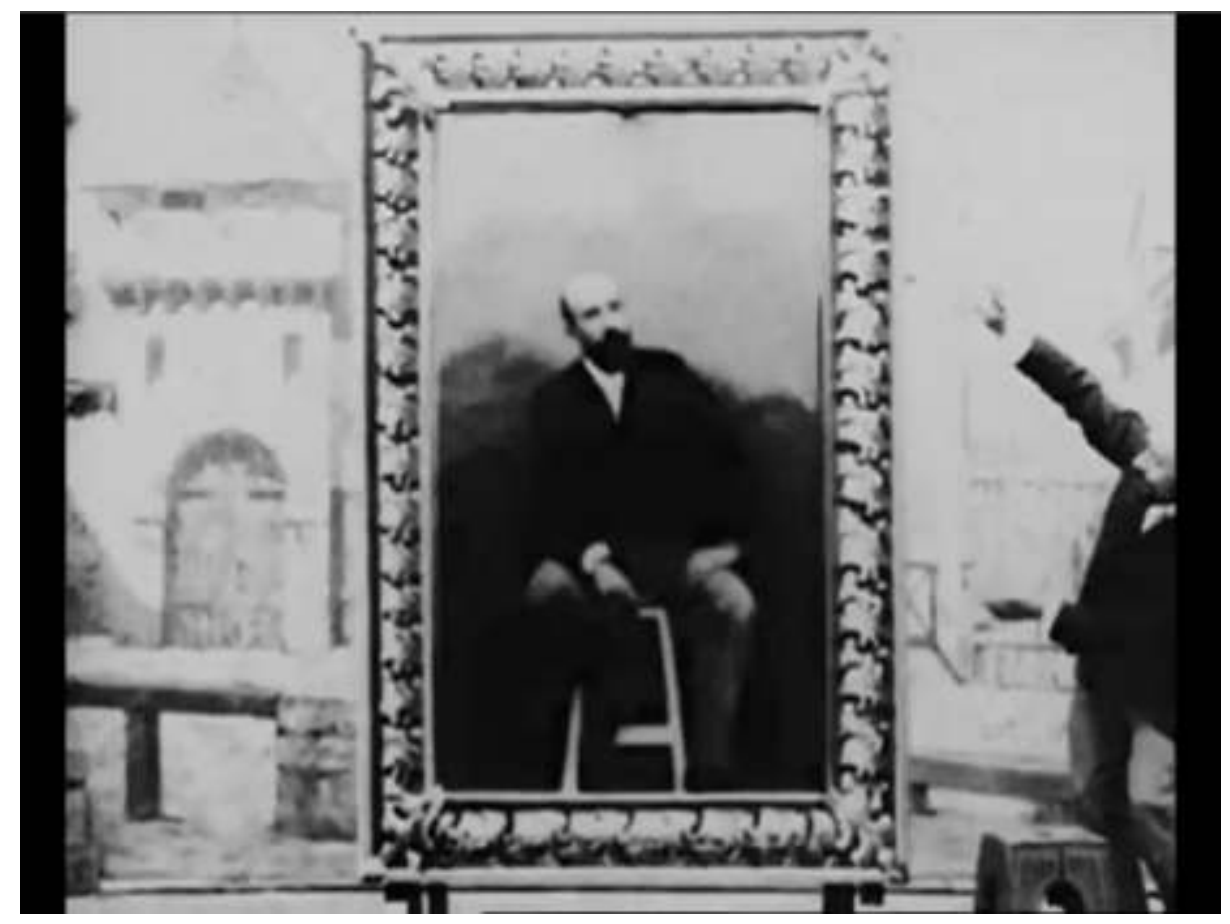

Fig. 3: A Mysterious Portrait (Georges Méliès, 1899)

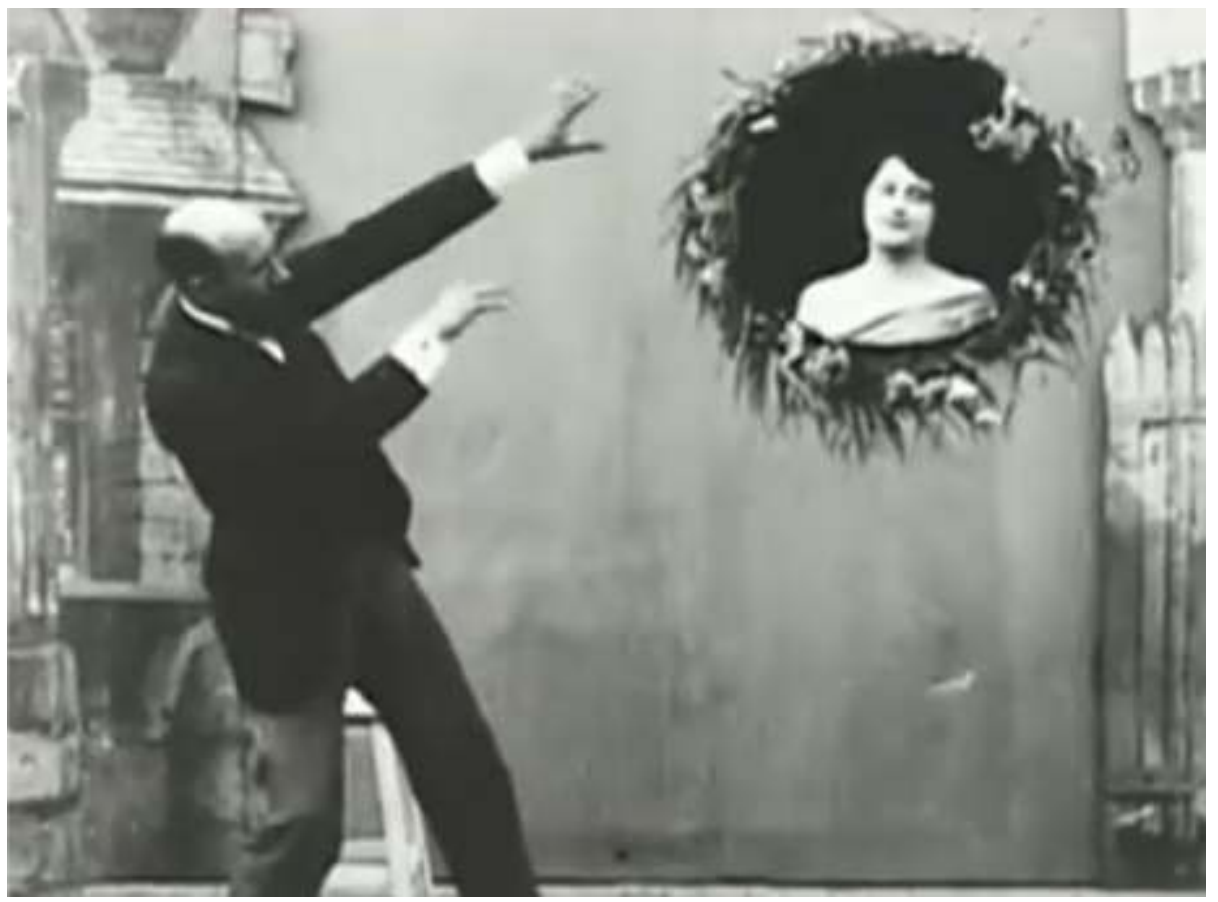

Fig. 4: Summoning the Spirits (Georges Méliès, 1899)

Here is the primitive form of the control of (in)visibility: in early cinema, the ability to make images or to erase them is a meta gesture, a half-veiled replica of the filmmaker's ability to frame the visible world, and to regulate its manifestation. One must learn to 
tame images, conjure and reject them, in order to make sense of them. In a lecture given on October 3, 2018 at the Université de Paris, during his workshop 'Feintes, Fictions, Figures: Images de l'Invisible', Jacques Aumont claimed that there are two forms of invisibility. One is circumstantial, caused by temporary concealment. The other is essential. It is neither an accidental quality, a shortcoming of visibility, nor a degraded version of visibility. Making things invisible is an art form in itself, which can be as supernatural and spectacular as the art of generating images. Early cinema depicts the fascination not only for what comes to light, but also for what escapes the grasp of our senses.

\section{Puffs of Smoke: Vanishing Acts between Vaudeville and Crime}

These image conjurors, interpreted by Méliès himself, mimic the role of the filmmaker, taming the intermittence of light that structures the apparition and vanishing of figures on screen. But very quickly, early cinema displayed a larger reservoir of characters that enact more than the meta reference to the projection of light, and hint at the criminalization of vanishing acts. While the subgenre of the cop chase set ground for the Keystone cops and the foundation of the Chaplinian exercise in fooling authority figures, we can argue that it also provided a larger number of representations of the fluctuation of identity, and the art of escaping the identification apparatuses championed by the police in the late $19^{\text {th }}$ and early $20^{\text {th }}$ century.

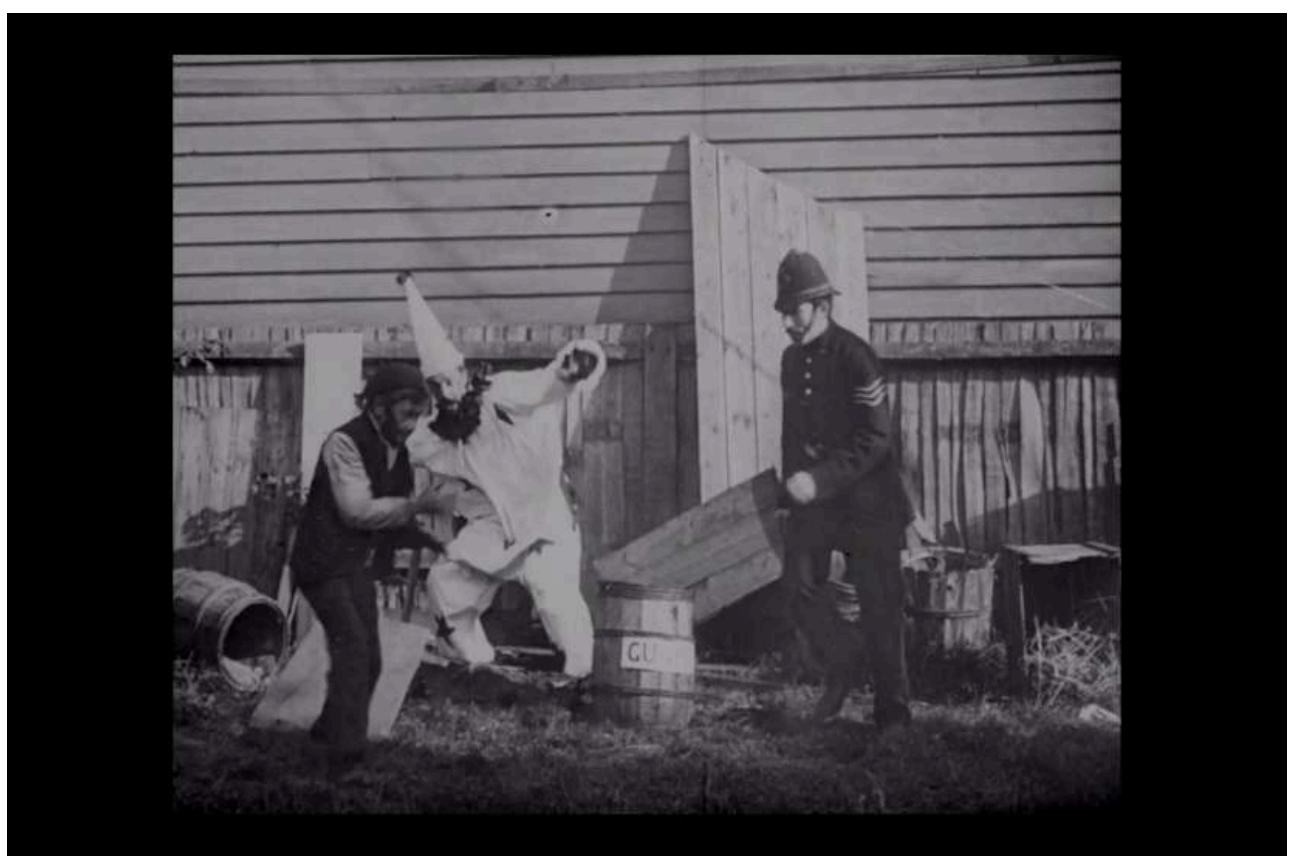



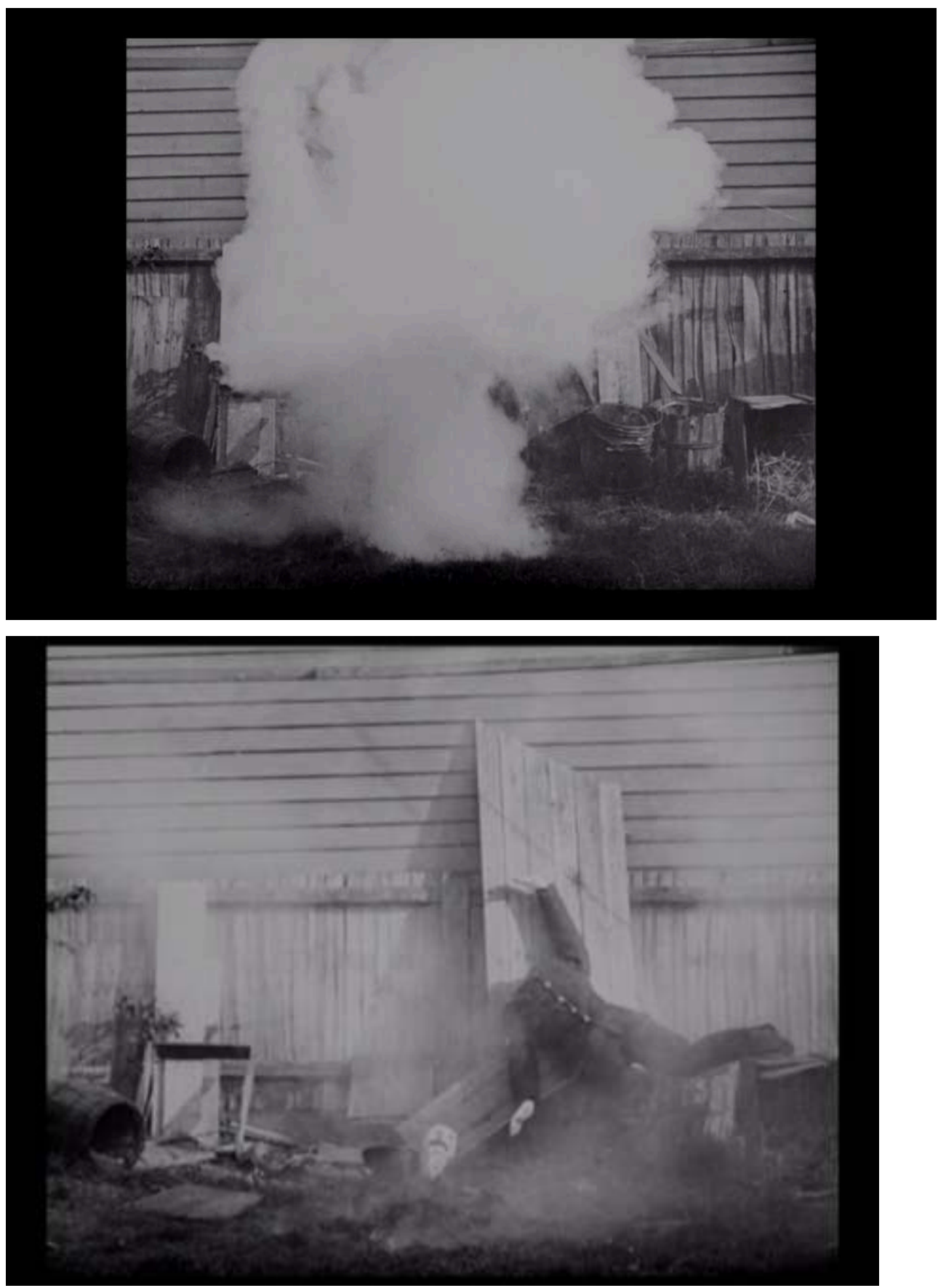

Fig. 5-7: Clown and Police (Cecil M. Hepworth, 1900)

A British film called Clown and Police (Cecil M. Hepworth, 1900, Fig. 5-7) performs the convergence of the worlds of vaudevillian tricks and the police chase. In an unkept backyard, a clown in white suit and his accomplice set up a small barrel of gunpowder. A Bobby comes around and attempts to arrest the clown, who freezes and vanishes, leaving the police agent puzzled and angry. Just as the agent sits down on the barrel, it explodes into a large puff of smoke and beheads him. The clown and his accomplice return, toying with the corpse, placing the head back on its body. But the policeman comes back to life and grabs the clown, who dematerializes, leaving only his costume to twist and shake around. 
This short film sees a collision of two worlds, the delirious and irrational transformations of the clown, and the base world of urban criminality, which has been depicted on film as early as 1896 in Robert W. Paul's Footpads. Clown and Police is, in this regard, an encounter of two distinct filmic genres: that of the vaudeville magician trick recorded and displayed on screen, mimicking fairground and music-hall routines, which was one of the staples of early cinema, and that of the police chase. Through this encounter, the clown's tricks suddenly cross over from one domain to the other, from the playful universe of tricks and illusions, to the realm of criminality. In this crossover, cinema seems to be on the side of the trickster. All forms of vanishing are meant to confuse the police agent: the clown's spontaneous disappearance, the puff-ofsmoke explosion, and the clown's final evanescence, which leaves his clothes behind, but not his body. There is much to be said about this three-fold exploration of invisibility. Around 1900, cinema seemed to deny the fact that police arrest and identification techniques grew more complex and more technologically intricate. Rather, it represented policemen as baffled, grotesque individuals. In what might be seen as a sort of reaction to the increasingly sophisticated instruments to prevent crime, cinema depicted fooling the police as a delirious art that criminals relished and in which policemen looked the fool.

Clown and Police goes further into the exploration of the aesthetics of invisibility. In films by Méliès, the magician reigned over the apparition and disappearance of the world around him; he, himself, remained visible. As the conductor, he was the only permanent body in a universe ruled by impermanence. In Clown and Police, the trickster organizes his own disappearance, while the world around him remains stable. The art of invisibility becomes the art of turning oneself invisible, as a form of strategic escapism. The presence of a police agent radicalizes and criminalizes the art of vanishment: the clown's puff of smoke suddenly displays its criminal potential, when used to fool the police. We can already perceive here a primitive form of camouflage, through the interactions between conjurers and police. This will be discussed at length when we explore the variety of camouflage aesthetics in film. Films like Clown and Police show that cinematographic tricks can serve a vanishing function, not simply a revelatory one.

We can observe several distinct modes of invisibility, in Clown and Police, which further point to the fundamental complicity between cinema and the art of vanishing. There are two main forms of disappearance. One is achieved by purely cinematographic processes: the edited suppression of the clown's body, which merges the magician's powers with that of cinema itself. The other, which consists in the explosion of the powder barrel, creates a temporary cloud of smoke, masking any visible body that belongs to the diegetic world, not to the editing process itself. Whereas the policeman remains vulnerable to the dangers of the diegetic world, the clown seems to exist through the very process of the fabrication of the film, slipping away between one frame and the other. The clown, here, shares the power of the conductor-conjuror persona of the 1899 Méliès films, organizing the play on apparition and evanescence. But in Clown and Police, the ability to disappear goes beyond the domain of trick-making and fairground amusement, stepping into the realm of police authority. The presence of the policeman grounds this vanishing trick into potentially criminal territory: it depicts the trickster's puff of smoke as a camouflage technique. 
This push and pull movement, from the exercise of authority to the imaginary or pragmatic invention of modes of resistance, has been described by Gary T. Marx as "neutralization" and "counter-neutralization" techniques. ${ }^{12}$ The cases featured in this paper support the analysis of surveillance and police control as a movement of mutual adaptation and counter-adaptation between those who practice surveillance and those who are subjected to it. They support the argument according to which "surveillance needs to be viewed as a dynamic process involving emergent interaction and developments over time with respect to anti- and pro-surveillance actions." ${ }^{13}$ Films such as Clown and Police support the idea that cinema accompanied the invention of invisibility, in the form of a crossover between vaudevillian spectacle and the art of escaping the police. As such, this film suggests that surveillance has always been approached and negotiated through seemingly light forms of entertainment. In reality, vanishing acts depict deeper correlations between surveillance techniques and the invention of resistance to these techniques. The criminality of the vanishing act depicted in Clown and Police establishes a direct correlation with the development of police investigation techniques that emerged in the late $19^{\text {th }}$ century. Around 1900, anthropometric techniques were at the foreground of police practices. Alphonse Bertillon and Francis Galton led a new era of scientific investigation, championing a foolproof, fully equipped police force. At the same time, early film comedy mocked the police on the very grounds that were defended by the advocates of the scientific police: by depicting blind or hallucinating agents, who cannot deal with the metamorphic powers of the bodies that Anthropometry claims to have tamed.

\section{Metamorphism}

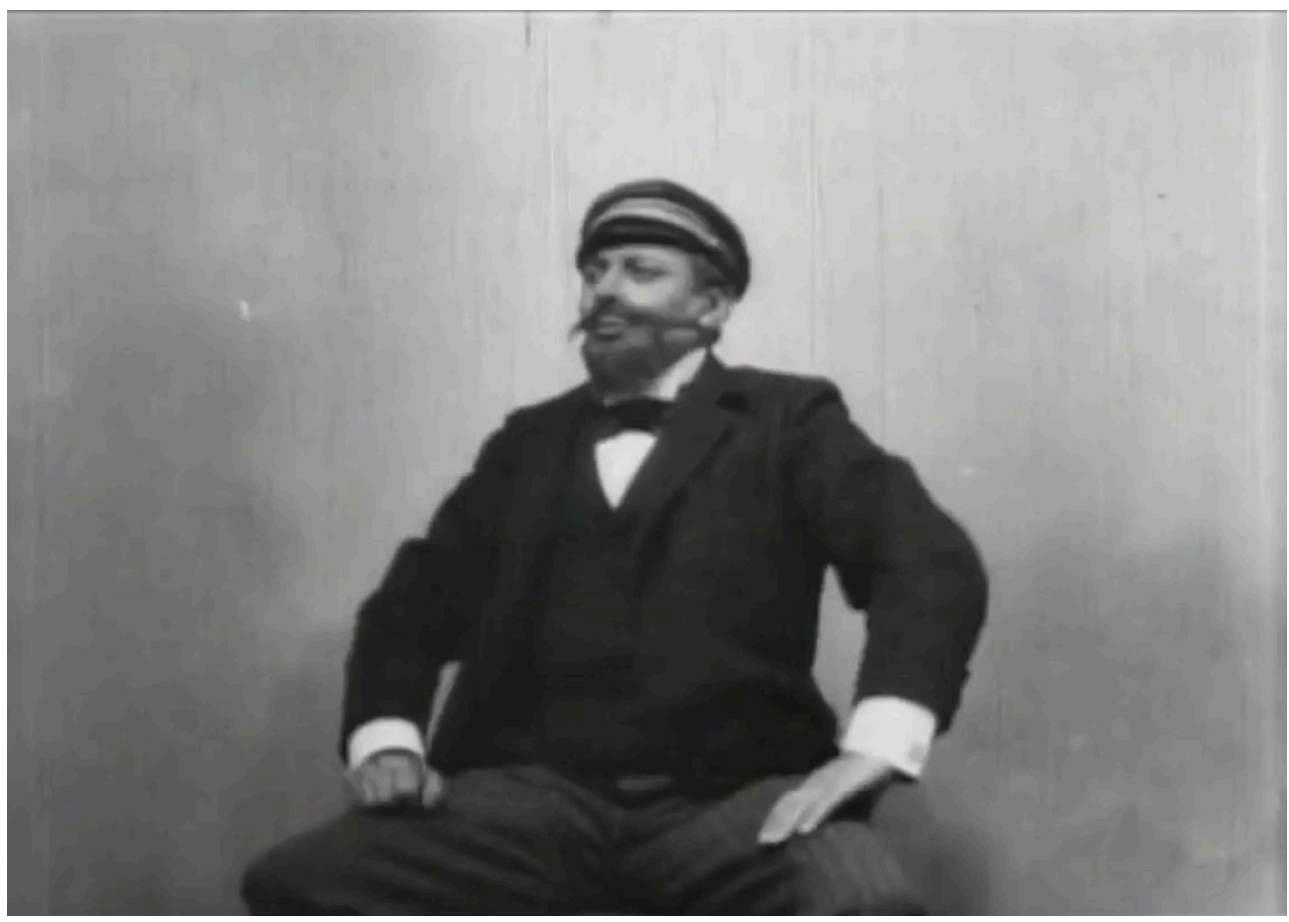




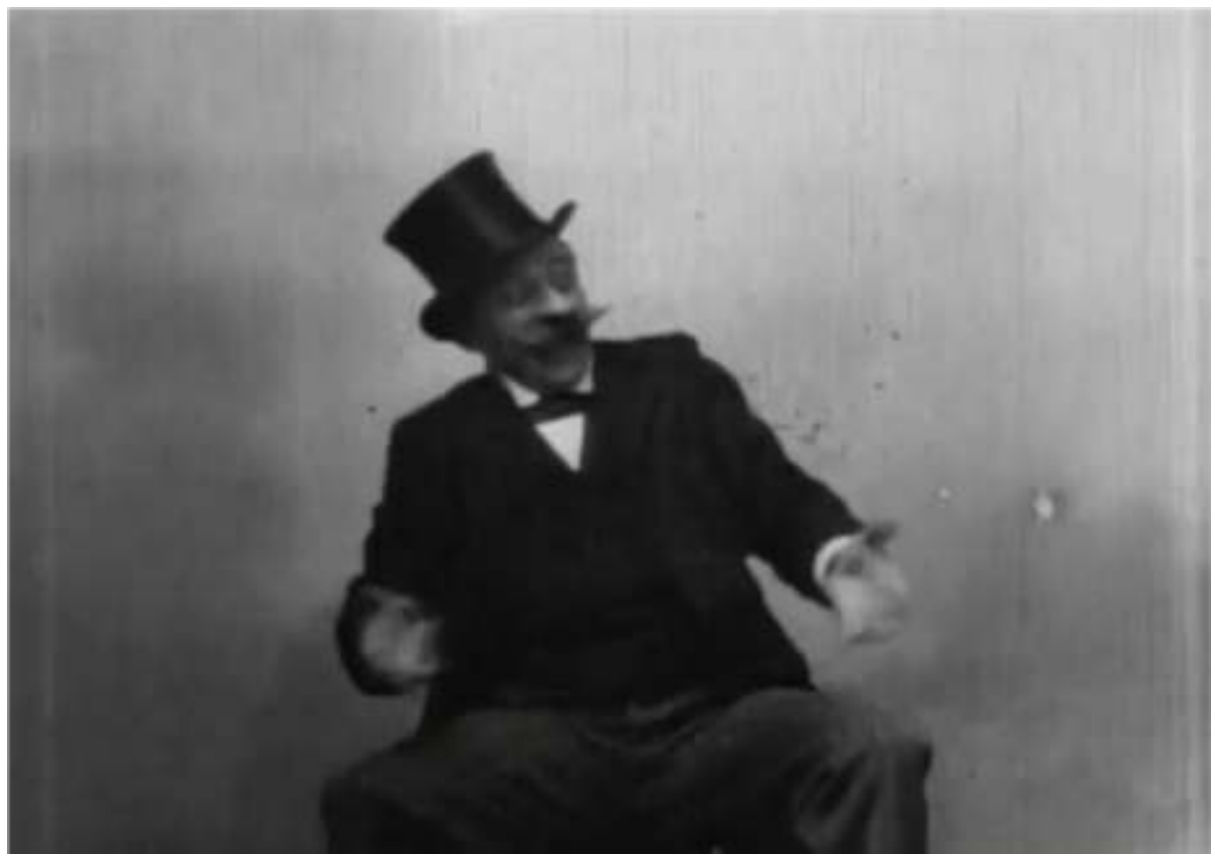

Fig. 8-9: Coiffures (Lumière catalog, 1896)

Puffs of smoke and magic tricks offer only a fragment of the spectacle of invisibility displayed by early cinema. Disappearing by ceasing to be perceptible altogether is only one way of becoming "invisible." Cinema cannot deal with sheer invisibility; it needs a tangible, manifest sign of the body or object that just vanished. The clown's empty suit, shaken by the policeman at the end of Clown and Police, constitutes one of the manifestations of an absence. There are other ways to represent that which escapes. One of them is the rapid metamorphism or the fluctuation of appearances. Two twin films from the Lumière catalog illustrate such fascination for the ability to make oneself unrecognizable through physical, and particularly, facial disguise. Coiffures and Chapeaux à transformations, both from 1896, illustrate the art of transforming one's appearance with great effect and minimal tools. In Coiffures (or "Headdresses", Fig. 8-9), a sitting man puts on and takes off half a dozen hats and hairpieces in forty seconds, providing facial transformations at a dizzying pace. The effect is comical; most disguises display caricatural features, and all are enhanced, or amplified, by the actor's grotesque facial contortions. A handful of wigs provide enough material to create, on the spot, many unmistakably different characters. Coiffures is, in other terms, a demonstration of the metamorphic powers of the filmic body. It is also a masterclass in acting, displaying the actor's wide range in a series of rapid transformations.

Chapeaux à transformations follows the same principle. In a setting comparable to that of Coiffures, a sitting man puts a small, foldable hat on. He then proceeds to take it off, unfold it and fold it again into a different shape, creating a series of nine portraits, complementing each headpiece with a corresponding facial transformation. Each of these portraits, as in Coiffures, evokes an easily recognizable character trope: the idiot, the religious bigot, the buffoon, and so on. The paper hat provides a minimal tool for self-transformation, hinting at the versatility of facial appearances on screen. Once again, the art of taming the mutability of appearance is tightly connected to 
cinematographic principles: both films work as exhibitions of the actors' range and illustrate that the human face, on screen, denotes falsification.

Metamorphism, here, must be understood as the process that disturbs physiological recognition. As such, cinema offers the spectacle of various successive identities, but also of the very process through which this variation exists. This fascination for facial transformation played a decisive role in the construction of discreet heroes, such as Fantômas, born in the novels of Pierre Souvestre and Marcel Allain in 1911 and brought to life on screen in 1914 by Louis Feuillade. The screen serial adaptation of Souvestre and Allain's novels pays a direct tribute to Coiffures and Chapeaux à transformations: each episode opens with a series of shots of the main character, Detective Jouve, flanked by varying hairpieces and facial apparatuses, which represent the sleuth's attempt at matching his archenemy's face-shifting skills. Hence, Fantômas brings together two correlated domains: cinematographic metamorphism and the art of police avoidance. The skill of transformation is shared by actors and criminals alike. Under Feuillade's lens, the figure of Fantômas emerges as the purely cinematographic hero of appearance forgery. Indeed, it is significant that the opening images do not show Fantômas, the face-shifting criminal, but Jouve in various headpieces. In Fantômas's world, metamorphism is a contagious disease. Only transformists can hope to catch the ultimate transformist himself, Fantômas. In other words, Fantômas extends the metamorphic experiments of Coiffures and Chapeaux à transformations to a global filmic universe: the trick becomes the rule, and the trickster, Fantômas, dictates his falsifying law to the world he inhabits. Fantômas expresses literally what could only be identified as a subtext to Clown and Police: the fragmentation of the body serves diametrically opposed functions. In filmic form, Fantômas's puzzled anatomy helps him escape from the police, while at the same time, the cutting of the body into discreet motifs constitute the core technique of Anthropometry. The early cinema of transformation highlights the volatility of the human (and, in particular, criminal) body in competition with the police techniques of identification and early biometrics, which aimed at the systematic and foolproof decoding of biometric signs: the fugitive and the sleuth share a similar belief: that fragmentation will ensure their triumph.

We will now observe how cinema inquired further into the resistance of the human body under Anthropometric surveillance, through the art of becoming undecipherable. This strategy differs from the skill of pure invisibility. Rather, it works within the domain of the visible, but focuses on bodies that resist the treatment that turns them into readable signs. In other terms, it paves the ground for a reflection on selffalsification.

\section{Self-Falsification}

\section{Resisting Photography}

A pair of twin films from 1904 depicts the fictionalized, but disturbingly realistic photographic arrest of a young woman, and her attempt at distorting her face to disrupt the capture of her portrait. Subject for the Rogue's Gallery (Fig. 10) and Photographing a Female Crook (Fig. 11), both produced by the American Mutoscope and Biograph Company show the perturbation of the routine capture of the image of a female criminal who, as The Library of Congress Paper Print Collection explains, "is 
grimacing and distorting her face in an attempt to disguise her identity." ${ }^{14}$ Two police agents (in Photographing a Female Crook), helped by the photographer himself in Subject for the Rogue's Gallery, maintain her head still in front of the image-capturing devicebut in both cases, she frowns and winces, and eventually ends up crying, twisting her face into a disfiguring grimace. Presumably shot on the same day and at the same location, these films go deeper into the mechanics of police identification and bodily surveillance, and into the depiction of how to neutralize individuals. Keeping the vaudevillian tricks of Clown and Police in mind, they extend the encounter between the techno-judiciary apparatus and the spectacle of bodily tricks: whereas the clown's puff of smoke relied on editing techniques, these films thread on more realistic grounds, by showcasing the metamorphic power of a grimacing face.

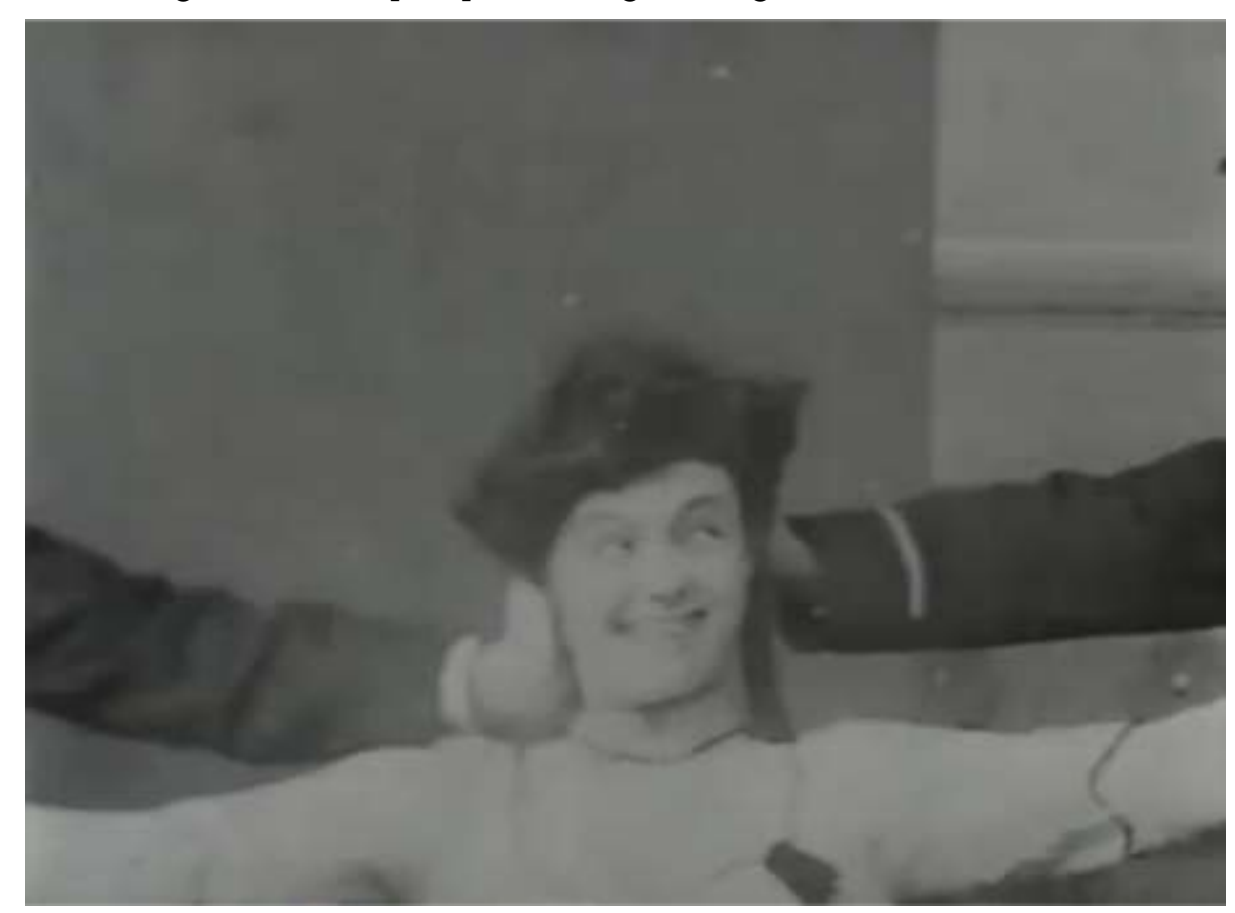


Fig. 10: Subject for the Rogue's Gallery (American Mutoscope and Biograph, 1904)

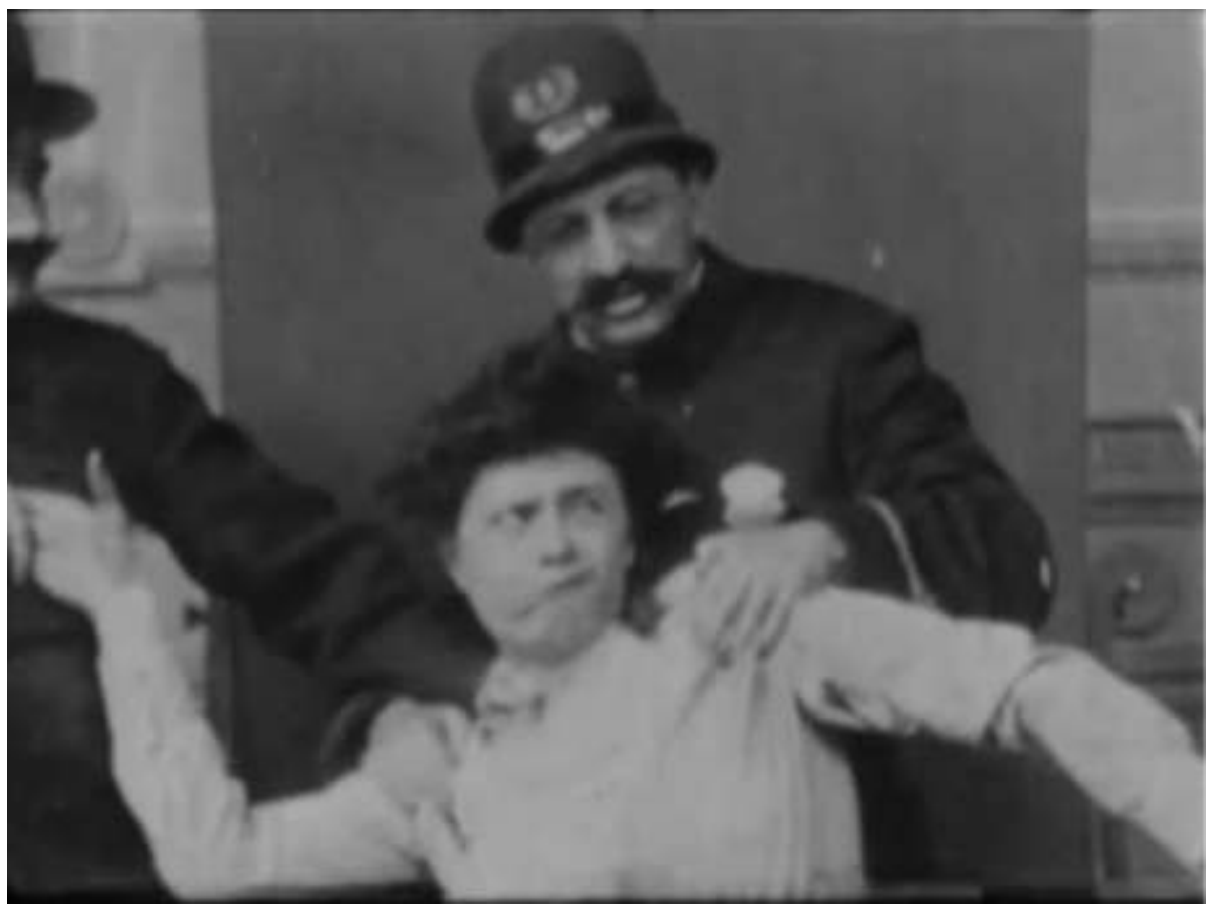

Fig. 11: One for the Rogue's Gallery (American Mutoscope and Biograph, 1904)

The representation of photographic portraiture under the authority of the police, while diving deeper into the specifics of technological identification, mobilizes a type of female body that seems to have been imported from the realm of psychiatric and neurological pathology. It is striking to see a "crook" suddenly adopt the traits of the hysterical type, identified and archived at the Parisian Pitié-Salpêtrière since the middle of the $19^{\text {th }}$ century. Facial contortion, eye revulsion and violent contraction of the face are, indeed, very reminiscent of the hysterical episodes which fascinated physiologists and, soon, as Rae Beth Gordon has demonstrated extensively, popular entertainers on stage and on film ${ }^{15}$. A strange reversal takes place: where neurologists identified epileptic episodes precisely as moments where individuals (and in particular, women) found themselves deprived of any form of control over their movements, the female captive in Photographing a Female Crook and Subject for the Rogue's Gallery wields agency in the replication of epileptic-type movements. The paradox lies in the willful distortion of the face: there is a form of agency and control in abandoning oneself to the most chaotic forces that subject the woman's face to disfigurement. In this perspective, the photographic catalogues of epilepsy published since the $1870 \mathrm{~s}$ constitute a precious reservoir of faces that do not seem to resemble themselves. The whole process of photographic capture is also reversed. Where Jean-Martin Charcot and Albert Londe sought to provoke facial and bodily contortions in order to describe and characterize hysteria, these contortions appear here as the very tools that defeat the capturing and identifying functions of the camera.

In these films, the incursion into the world of biometric identification is on par with a diversification of resistance to the police. Here, resisting the police does not mean outrunning or beating agents anymore, as is the case in so many short films. The process of capture has been elongated, extended beyond handcuffing and throwing 
bodies in jail; from the late $19^{\text {th }}$ century on, it started to exist through image capturing. Stealth became necessary to escape from the agents themselves, but, more primarily so, from the devices used to produce images in order to identify, criminalize, and, potentially, convict individuals. "Resisting the police" also meant resisting the process of image generation that constituted a key feature in modern police practices. It is the process by which one asserts the way their image is captured, and, in retaliation, distorts, confuses, or ruins the capture of their image. The invention of "invisibility" is relative to the devices that generate oppressive forms of visibility. In this case, it is not disappearance that matters, but the ability to become unrecognizable by blurringalbeit temporarily-one's own appearance under the eye of the police camera. This specific type of resistance has a profoundly gendered history. Cesare Lombroso's $L a$ Donna Delinquente, ${ }^{16}$ from 1893, shows that while men were subjected to having their pictures taken when they committed offenses or crimes, moral and hygienic discourses sought to justify the investigation of the female body. In this regard, Lombroso's book expresses the intrinsic dangerosity of the female body, according to the European and, soon, North American police institutions: Female bodies and, in particular those of prostitutes, were systematically suspect (of carrying a disease, be it moral or physiological) and potentially criminal. As early as 1865 , the House of Commons of the British Parliament established the systematic control of prostitutes' bodies. ${ }^{17}$ This form of control spread over the second half of the $19^{\text {th }}$ century and well into the early $20^{\text {th }}$ century. Consequently, prostitutes developed modes of avoidance of institutional control in ways that involved the transformation of their body. Prostitution historian, Julia A. Laite, describes the way suffragettes and prostitutes attempted to scramble their photographic portrait, in a way that is very similar to that of the captive woman in the Mutoscope \& Biograph films:

As the District Superintendent of E Division (Holborn) said, prostitutes were known to 'change considerably in appearance' relying on the fact that 'time baffles recollection'. Perhaps prostitutes here employed a similar tactic to that of the suffragettes, who would move about in front of the prison warden's camera in order to blur their portrait. ${ }^{18}$

In an article summarizing the main contributions of fingerprint collection, Laite describes the double limitations of the criminal portrait. First of all, it captures individual appearances at a specific moment, and thus, it is subject to the passing of time, the aging of the body, which transforms faces slowly but steadily-contrasting with the steady nature of fingerprints. Therefore, the photographic portrait must be updated regularly in order to maintain resemblance to the individual it depicts. In addition to this, the photographic portrait was skewed by the action of the photographed themselves. Prostitutes and suffragettes (and their filmic equivalent) developed a bodily jamming device: their own face, and their ability to exhibit a variety of non-resembling images by contorting their facial features. Yet it is not sufficient to say that these two films promote and glorify self-counterfeiting. It is true that these techniques are demonstrated on screen, but it seems that cinema flirts with the function of the photographic apparatus, rather than acting as an accomplice to the resistant body. The camera movement is indeed slowly closing in on the captive's face, replicating the photographic capture that is organized in the police station. It is as if cinema was an extension of the police apparatus itself, and the captive is being exposed to the movie camera, just as she is being offered to the police's camera. 
French historian Jean-Lucien Sanchez, who specializes in anthropometrics and in the history of persistent offense, mentions the agitation of captives under the photographic gaze, in an article retracing the history of Frédéric Seveyras. Accused of stealing in 1890, Seveyras pleaded not guilty, pretending to be an Austrian citizen, which would have earned him the right to be expelled to Austria, and not sent to the hard labour camps in French-controlled New Caledonia. Sanchez explains that Seveyras tried fooling photographic identification, which would have exposed his fake identity: In order to check his declaration, an identification procedure was engaged in the detention house where he was held, but because of Seveyras's agitation in front of the agent who was supposed to take a picture of him, no image susceptible of identifying him could be produced. ${ }^{19}$

The generation of an image comes as a trial before the trial; any attempt to escape it is seen as a proof of guilt. Many historians have noted that the normalization of biometrics implies a form of compliance, and that the refusal to submit one's bodily information signals potential criminality. The submission to the photographic camera was, maybe, the most primitive form of biometric identification; it engaged recognition, not the reading of encoded signs. We will now see how the art of becoming unrecognizable engaged with a miniaturization of the criminal image, which had to do not only with the photographic portrait, but also with discreet signs emitted from various parts of the body.

\section{The Disfiguration Strategy}

In a paper presented to the British Royal Society of Arts on March $16^{\text {th }}, 1921$, forensic scientist and handwriting expert $\mathrm{C}$. Ainsworth Mitchell evaluated the efficiency of the tools used in the scientific investigation of crime. ${ }^{20}$ While praising the recent improvements in communication among various departments devoted to the detection of criminals, he admitted that, "in spite of having to contend with all the resources of science and art at the disposal of the authorities, the natural astuteness of the criminal mind not infrequently proves a more effective weapon." ${ }^{21}$ Mitchell identified a fundamental dialectic between the intuitive skill of the criminal mind (its "natural astuteness"), and the fastidious devising of technological tools by the scientific police. Photography was no exception:

The invention of photography placed a new weapon in the hands of the police authorities for establishing the identity of a "wanted" person. In many cases it has led to the detection of a criminal, but on the other hand, is not proof against efficient disguise. Moreover, since a photograph represents only one aspect, and that often a false one, of a person at a particular moment, there is often a chance of its being mistaken for that of someone else. ${ }^{22}$

Mitchell characterizes photography as a doubly imperfect device. First of all, it cannot guarantee the identification of a singular person. Photographic portraiture immobilizes the face, reducing it to a simplified version of itself, and thus to a certain falseness, leading to potential misidentification. But physical dissimilarity between the portrait and the "real face" is not the only limitation of photographic identification. "Efficient disguise" can also fool recognition. In other terms, the voluntary alteration of one's appearance is a potential bug in identification processes. Through the study of metamorphism sequences, we observed the fascination expressed by early cinema for 
hairpieces and hats (Coiffures and Chapeaux à transformations) and fake facial apparatuses (Fantômas). We will now focus on the radicalization of appearance alteration, in scientific discourse, in public cases and in film. This radicalization consists in altering the body itself in a permanent way. The early 1900s saw the widespread circulation of information regarding biometric techniques. By the 1910s and 1920s, fingerprinting had entered popular culture in Europe and in North America. Fantômas, once again, was at the forefront of the depiction of identification techniques. In the third episode of the serial directed by Louis Feuillade, the sensational criminal cuts off the skin from the hand of one of his victims and wears it as a glove. Spreading the dead man's prints all over the scenes of the crimes he commits, Fantômas appears as one of the first antiheroes of the biometric era. The figure of John Dillinger crystallized both popular fascination and scientific concern regarding criminal self-falsification. His attempts at disfiguring himself and burning his own fingertips using acid are well-documented. ${ }^{23}$ We can argue that Dillinger's attempt at modifying his own body was a reaction to the recent amplification of the means devoted by the police to ensure the recognition of individual criminals. The Prohibition on the production and distribution of alcohol, which lasted from 1919 to 1933 in the United States, amplified the means devoted to surveillance and identification. In 1924, J. Edgar Hoover was appointed Assistant Director of the Bureau of Investigation. He was at the forefront of the creation of an "Identification Division," under which "local police fingerprint files and federal files began to be amalgamated into a central resource". ${ }^{24}$ Dillinger's notorious disfigurement attempts expressed a radical transformation of what it took to escape police surveillance and identification techniques. The integrity of the body had to be sacrificed in order to become unreadable. A leading case in the strategic degradation of the body, Dillinger's "career" motivated scientists to consider the efficiency of surgery to avoid police detection. In a 1935 paper ${ }^{25}$ presented before the Society of Plastic and Reconstructive Surgery, facial surgeon Jacques Maliniak summed up what John Dillinger's disfigurement strategy implied for the relationship between surgeons and the police. His conclusions were rather worrying:

At the present time there is no means of knowing how many criminals have had recourse to plastic surgery in the attempt to conceal their identity. There can be no doubt of the possibility of effectively disguising the appearance by this means; and the fact that it has been attempted by a few notorious criminals leaves little doubt that it will be tried again. This constitutes a serious problem for the reputable plastic surgeon no less than for the police. [...] Closer cooperation between plastic surgeons and the authorities would go far to prevent the witting or unwitting prostitution of an honorable specialty to the purposes of crime. All legitimate reconstructive surgeons should be listed with both local police and the Department of Justice. ${ }^{26}$

\section{Invisible, Undetectable}

The lesson of the "Dillinger moment" exceeds the case of the notorious criminal. Hollywood stars turned to facial transformation, too. The worry expressed in Maliniak's article can be related to an intriguing new trend of the 1920s, which consisted in the ability to willfully alter one's own facial features. This constitutes a key moment in the invention of invisibility. Here, the goal is unreadability, be it of the face or of the finger prints; the art of altering one's own appearance. It is not surprising that the art of differing from one's native appearance came as a prominent issue for the scientific police. 
The case of John Dillinger instilled the idea that the alteration of one's own body could trick identification processes. In this regard, falsification took shape through a variety of ways of blurring the signs that the body emits naturally. Dillinger's alteration is skin deep, it cuts, literally, through the skin in order to generate falsified signs - mutilated fingerprints and rearranged facial features that do not match biometric databases. Such modes of self-counterfeiting produce deficient identification; they work within the gap that exists between individual appearances and their pictorial replicas. The result is not pure invisibility (the sensible absence of a body, or of traces of a body), but a form of loose image, be it blurred under the police photographer's eye, or scraped at the end of the fingertips. In both instances, resistance to identification devices comes from a deep conscience of giving oneself away as an image; and, consequently, from the ability to affect the legibility of this auto-image.

The Bureau of Investigation (which became the Federal Bureau of Investigation in 1933) commissioned a short film in 1936. Produced by Universal, You Can't Get Away With It showcases the resources of the Bureau against organized crime and aims at legitimizing routine fingerprinting "for protection." The dead body of John Dillinger makes an appearance and the viewer learns that he spent five thousand dollars trying to burn his fingerprints with acid, without success. You Can't Get Away With It formulates an implicit response to the popular fascination for the crimes and transformations undertaken by John Dillinger. It aims to depict the Identification Division as a foolproof entity. The most striking aspect of the demise of John Dillinger lies in the way the FBI attempted not only to capture and kill the gangster but, most importantly, to control the destiny of his image.

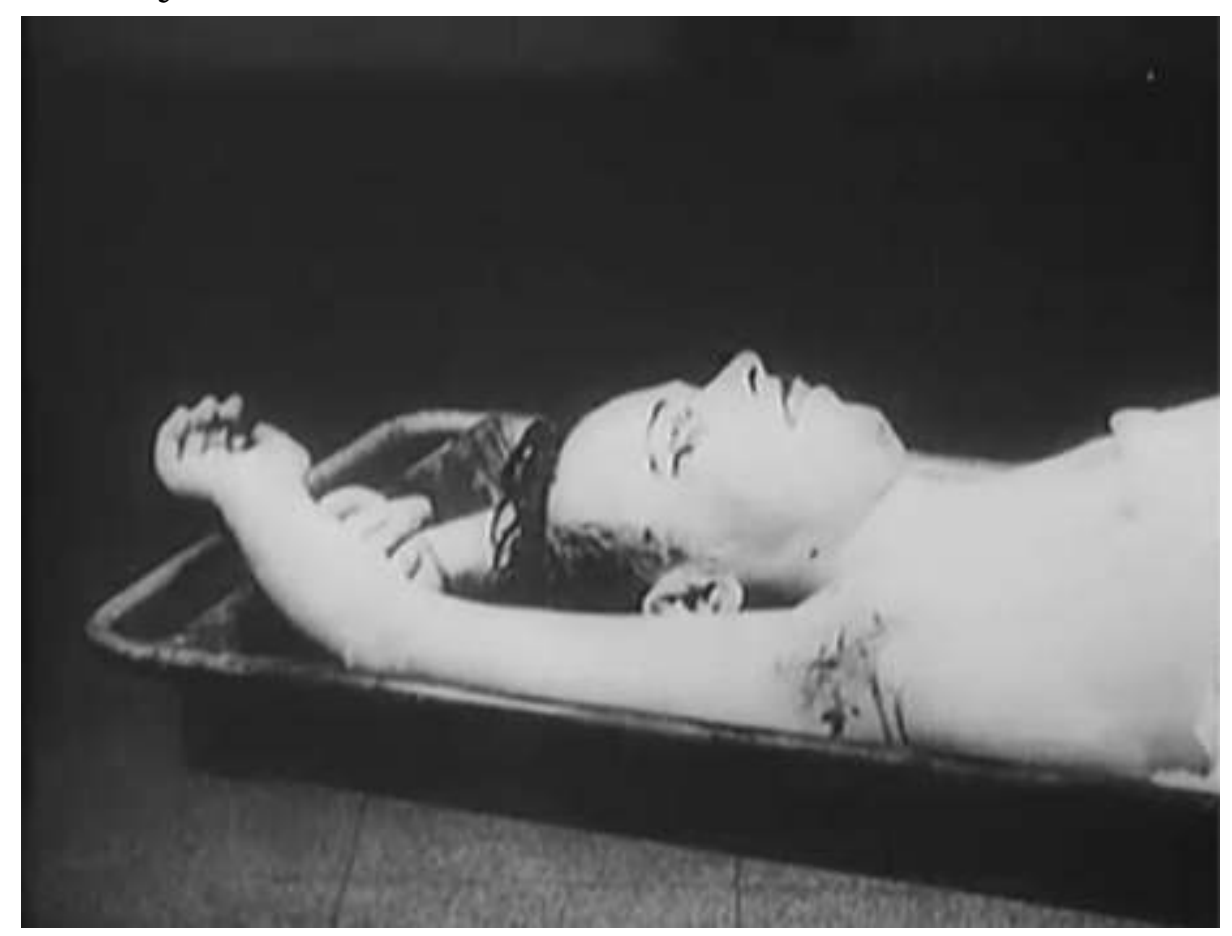

Fig. 12: You Can't Get Away With It (Charles E. Ford, 1936)

His death was not enough: the duel between the FBI and him was instantly perceived by its protagonists as legend-making. And, to ensure that they would have the glory, the FBI made sure to be the sole heroes to emerge from their duel. Anticipating the 
recuperation of the gangster's figure by Hollywood, Hoover prohibited studios from producing any motion pictures depicting the life of John Dillinger. In an article that retraces the emergence of the "G-Man" character, Carlos Clarens mentions a telegram sent by Will Hays, then Chairman of the Motion Picture Producers Association, to MPPA censor Joseph Breen, days after the FBI: "No motion picture on the life or exploits of John Dillinger will be produced, distributed, or exhibited by any member [of the MMPA] [...]. This decision is based on the belief that the production, distribution, or exhibition of such a picture could be detrimental to the best public interest. Advise all studio heads accordingly." ${ }^{27}$ In accordance with Hoover's instructions, the studios strategically organized Dillinger's absence from theatre screens, so as to ensure that the Government Men (or "G-Men") would be the sole heroes of the myth-making function of Hollywood cinema. Invisibilization, here, is a tool in the hands of the FBIcensured movie studios. Or, rather than the pure disappearance of John Dillinger's image, the FBI limited the apparitions of the gangster to images of his demise. Dillinger was made visible only through iconic images of his dead body, images that acquired the value of war trophies, which were exhibited on screen by the FBI. In other words, the suppression of Dillinger's identity from Hollywood screens was meant to invisibilize the success of invisibilization techniques: making sure that the self-counterfeiting gangster remained hidden from the public eye.

In his article, Clarens notes that the end of the Second World War "defused [the image] of the gangster." ${ }^{28} \mathrm{He}$ argues that the success of Max Nosseck's 1945 Dillinger showed that the return to the gangster film, "after years of large-scale mayhem and destruction, becomes a curious affirmation of a traditional way of life and death." ${ }^{29}$ Yet the trivialization of John Dillinger in movies also put body-altering techniques at the foreground of the filmic depiction of crime. In 1946, Phil Karlson's Charlie Chan: Dark Alibi features a forged fingerprint. The key to the mystery lies in the scientific police's demonstration that the print was fake (because of a lack of natural oil on the surface), and in the forensic technician's meticulous recreation of the artificial hand used to leave counterfeited prints all over the crime scene. The scientific investigation and the scientific execution of crime in Dark Alibi premiered the longstanding dialogue between self-falsification and the technical ability to deter it, which is still active in contemporary scientific publications in the world of FRAPS (Facial Recognition After Plastic Surgery) ${ }^{30}$ and crime movies.

\section{The Mask of Cinema}

Modern-day activism faces new forms of identification techniques; mostly, that of automated and massified facial recognition devices. In reaction to the routinization of surveillance and identification techniques, we can observe the emergence of a type of resistance that implies not the deterioration of oneself (as was the case with Dillinger's surgical disfigurement), but the parasitic accumulation of visual elements, which provokes a form of visual and information overload. Invisibility, in the digital age, is the product of an excess-rather than of a retention of visible information. Digital media offer both an opportunity for surveillance and for self-falsification.

Digital artist Jing-cai Liu can help us perceive how cinema itself can replace plastic surgery, or bodily alterations of any kind, in contemporary fantasies of camouflage and resistance to identification devices. Liu's Wearable Face Projector (2017) is a mask made 
of light, which is emitted by an built-in device that users wear like a headband, or a thin helmet. In the artist's words: "A small beamer projects a different appearance on your face, giving you a completely new appearance. This product protects you from privacy violations." ${ }^{31}$ The projection of virtual faces on the user's own skin points to the counterfeiting capacity of a device that recalls the basic principles of cinema: the projection of light on a screen. There is indeed a strange return of the classic apparatus here, with the beamer replacing the film projector, and the face replacing the screen. Moreover, the masks of light projector famous actors and actresses' faces, completing Liu's Wearable Face Projector as an avatar of cinema.

It is as if the most basic and archaic tools of cinema-the projection of light on a blank screen-were rescued and turned into the tools of resistance against the algorithmic treatment of the face. The rescue here is mutual: resistance rescues cinema, which rescues resistants from identification. Here, the ancestral instruments of cinematographic projection serve a counterfeiting function, by flooding the identification systems with a flow of parasitic faces made of light. Liu's Wearable Face Projector enables us to formulate a diagnosis regarding the relationship between cinema and the politics of self-counterfeiting: cinema is not merely a tool for the depiction of counterfeiting gestures and techniques. It has become the raw material of selfcounterfeiting. Cinema does not display or illustrate neutralization techniques, it is the neutralization technique itself. Moving light is the raw material that is used to confuse identification, and to melt the original face into a parade of shifting, volatile identities. Liu's work points to an alternative reading of the relationship between cinema and the tools of surveillance and identification: the principle of parasitic projection overcomes the principle of the capture of the visible. And, in doing so, it suggests that the decisive function of cinema does not necessarily lie in the revelation of the world (and of the human figure), but also in its falsification.

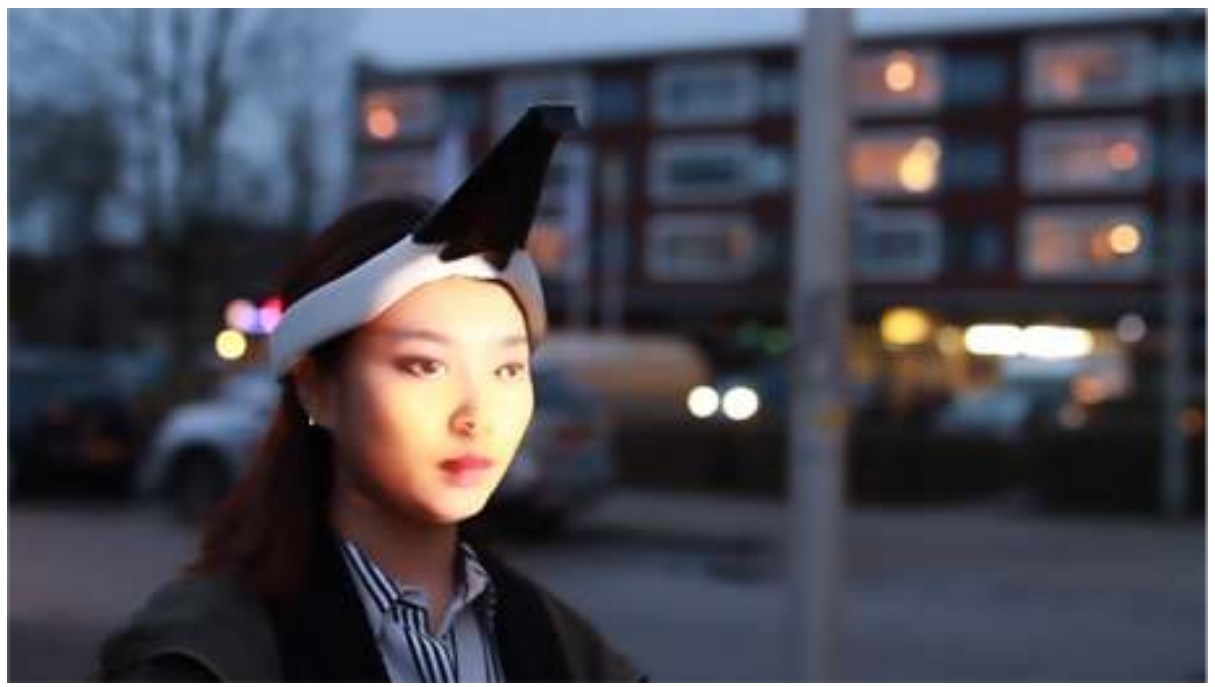

Fig. 13: Wearable Face Projector (Jing-cai Liu, 2017)

Albera, François. "Le Paradigme cinématographique." 1895. Mille huit cent quatre-vingtquinze 66 (2012): 8-33.

Barnouw, Erik. The Magician and the Cinema. New York and Oxford: Oxford University Press, 1981. 
Bullot, Erik. "Thoughts on Photogénie Plastique." In Jean Epstein. Critical Essays and New Translations, edited by Sarah Keller and Jason N. Paul, 245-253. Amsterdam: Amsterdam University Press, 2012.

Clarens, Carlos. “Hooverville West: The Hollywood G-Man, 1934-1945." Film Comment 13(3), (May-June 1977): 10-16.

Cummins, Harold. “Attempts to Alter and Obliterate Finger-Prints." Journal of Criminal Law and Criminology (1931-1951), 25(6), (Mar. - Apr., 1935): 982-991.

Galison, Peter and Paglen, Trevor. "The Lives of Images: Peter Galison in Conversation with Trevor Paglen.” Aperture 211, (Summer, 2013): 32-39

Gaudreault, André and Gunning, Tom. "Le cinéma des premiers temps: Un défi à l'histoire du cinéma?" In Histoire du cinéma. Nouvelles approches, edited by Jacques Aumont, André Gaudreault and Michel Marie, 49-63, Paris: Sorbonne-Nouvelle, 1989. Gunning, Tom. "The Cinema of Attraction[s]: Early Film, Its Spectator and the AvantGarde." In The Cinema of Attraction Reloaded, edited by Wanda Strauven, 381-388. Amsterdam: Amsterdam University Press, 2006.

Jäger, Jens. "Photography: A Means of Surveillance? Judicial Photography, 1850 to 1900." Crime, Histoire \& Sociétés / Crime, History \& Societies 5(1), (2001): 27-51.

Laite, Julia A. “Taking Nellie Johnson's Fingerprints: Prostitutes and Legal Identity in Early Twentieth-Century London." History Workshop Journal 56, (Spring, 2008): 96-116. Lefait, Sébastien. Surveillance on Screen: Monitoring Contemporary Films and Television Programs (Lanham, Toronto, and Plymouth, UK: The Scarecrow Press, INC., 2013. Liu, Xin, Shan, Shinguang, and Xilin Chen. "Face Recognition after Plastic Surgery: A Comprehensive Study." In Lee K.M., Matsushita Y., Rehg J.M., Hu Z. (eds.), Computer Vision - ACCV 2012, Lecture Notes in Computer Science 7725. Springer, Berlin, Heidelberg, 2013.

Liu, Jing-cai. Wearable Face Projector. 2017. http://jingcailiu.com/wearable-faceprojector/ <accessed on June $29^{\text {th }}, 2020>$

Lombroso, Cesare and Ferrero, Gugliermo. La Donna Delinquente. La Prostituta e la Donna Normale. Rome and Turin: Editori L. Roux \& Cie, 1893.

Maguire, Mark. “The Birth of Biometric Security.” Anthropology Today 25(2), (April 2009): 9-14.

Maliniak, Jacques W. “The Plastic Surgeon and Crime." Journal of Criminal Law and Criminology (1931-1951) 26(4), (November, 1935): 594-600.

Marx, Gary T. "A Tack in the Shoe and Taking off the Shoe: Neutralization and CounterNeutralization Dynamics." Surveillance \& Society 6(3), (2009): 295-306.

Mitchell, C. Ainsworth. "Science and the Investigation of Crime." Journal of the Royal Society of Arts 69(3570), (April 22, 1921): 353-394.

Niver, Kemp R. Motion Pictures from The Library of Congress Paper Print Collection 1894-1912. Berkeley and Los Angeles, University of California Press, 1967.

Parenti, Christian. The Soft Cage: Surveillance in America from Slavery to the War on Terror. New York: Basic Books, 2003.

Petersen, Julie K. Understanding Surveillance Technologies. Spy Devices, Privacy, History \& Applications, Revised and Expanded Second Edition. Boca Raton and New York: Auerbach Publications, 2007.

"Police Regulation of Prostitution." British Medical Journal (March $\left.4^{\text {th }}, 1865\right): 224-225$. Sekula, Allan. “The Body and the Archive." October 39, (Winter, 1986): 3-64.

Sanchez, Jean-Lucien. "L'anthropométrie au service de l'identification des récidivistes: L'exemple de la relégation en Guyane française." Criminocorpus [online], "Identification, 
contrôle et surveillance des personnes," May $12^{\text {th }}, 2011$. https://

journals.openedition.org/criminocorpus/365 <accessed on August $20^{\text {th }}, 2019$.

Solomon, Matthew. "Magicians and the Magic of Hollywood Cinema during the 1920's." In Performing Magic on the Western Stage. From the Eighteenth Century to the Present, edited by Lawrence Hass, Francesca Coppa, and James Peck, 61-84. Basingstoke: Palgrave Macmillan, 2008.

Tanupreet, Sabharwal, and Rashmi, Gupta. "Human Identification after Plastic Surgery Using Region Based Score Level Fusion of Local Facial Features." Journal of Information Security and Applications 48, (October, 2019).

Turner, John S. "Collapsing the Interior/Exterior Distinction: Surveillance, Spectacle, and Suspense in Popular Cinema", Wide Angle 20(4), (October, 1998): 93-123.

Turvey, Malcolm. Doubting Vision: Film and the Revelationist Tradition. Oxford: Oxford University Press, 2008.

Zimmer, Catherine. "Surveillance Cinema: Narrative Between Technology and Politics", Surveillance and Society 8(4), (2011): 427-440.

\section{NOTES}

1. Peter Galison and Trevor Paglen, "The Lives of Images: Peter Galison in Conversation with Trevor Paglen," Aperture 211, (Summer, 2013): 39.

2. Tom Gunning, "Tracing the Individual Body: Photography, Detectives, and Early Cinema", in Cinema and the Invention of Modern Life, eds. Leo Charney and Vanessa R. Schwartz (Berkeley: University of California Press, 1995), 35

3. Sébastien Lefait, Surveillance on Screen: Monitoring Contemporary Films and Television Programs (Lanham, Toronto, and Plymouth, UK: The Scarecrow Press, INC., 2013); John S. Turner, "Collapsing the Interior/Exterior Distinction: Surveillance, Spectacle, and Suspense in Popular Cinema", Wide Angle 20(4), (October, 1998): 93-123; Catherine Zimmer, "Surveillance Cinema: Narrative Between Technology and Politics", Surveillance and Society 8(4), (2011): 427-440.

4. Allan Sekula, "The Body and the Archive," October 39, (Winter, 1986): 3-64-not a specific page? The whole article?.

5. Mark Maguire, "The Birth of Biometric Security," Anthropology Today 25(2), (April 2009): 10-11.

6. Jens Jäger, "Photography: A Means of Surveillance? Judicial Photography, 1850 to 1900," Crime Histoire \& Sociétés / Crime, History \& Societies 5(1), (2001): 30-36

7. André Gaudreault and Tom Gunning, "Le cinéma des premiers temps: Un défi à l'histoire du cinéma?," in Histoire du cinéma. Nouvelles approches, eds. Jacques Aumont, André Gaudreault and Michel Marie (Paris: Sorbonne-Nouvelle, 1989), 49-63; Malcolm Turvey, Doubting Vision: Film and the revelationist tradition (Oxford: Oxford University Press, 2008).

8. Erik Barnouw, The Magician and the Cinema (New York and Oxford: Oxford University Press, 1981). Matthew Solomon, "Magicians and the Magic of Hollywood Cinema during the 1920's," in Performing Magic on the Western Stage: From the Eighteenth Century to the Present, eds. Lawrence Hass, Francesca Coppa and James Peck (Basingstoke: Palgrave Macmillan, 2008), 61-68.

9. Tom Gunning, "The Cinema of Attraction[s]: Early Film, Its Spectator and the Avant-Garde," in The Cinema of Attraction Reloaded, ed. Wanda Strauven (Amsterdam: Amsterdam University Press, 2006), 382. 
10. Inspired by the words of Athanasius Kircher, Elie Faure and Jean Epstein, Erik Bullot uses the metaphor of the volcano to characterize the nature of cinema: "Unstable and reactive, cinema's plasticity is a promise and a threat, a virtuality that may not be actualized. [...] Its effusiveexplosive history is that of a continuous-discontinuous invention, with the unpredictability of a volcano." Erik Bullot, "Thoughts on Photogénie Plastique", in Jean Epstein. Critical Essays and New Translations, eds. Sarah Keller and Jason N. Paul (Amsterdam, Amsterdam University Press, 2012), 250.

11. François Albera, "Le Paradigme cinématographique," 1895. Mille huit cent quatre-vingt-quinze 66, (2012): 23-30.

12. Gary T. Marx, "A Tack in the Shoe and Taking off the Shoe: Neutralization and CounterNeutralization Dynamics," Surveillance \& Society 6(3), (2009): 295-306.

13. Marx, "A Tack in the Shoe," 296.

14. Kemp R. Niver, Motion Pictures from The Library of Congress Paper Print Collection 1894-1912 (Berkeley and Los Angeles: University of California Press, 1967), 123.

15. Rae Beth Gordon, Why the French Love Jerry Lewis: From Cabaret to Early Cinema (Stanford: Stanford University Press, 2002).

16. Cesare Lombroso and Guglielmo Ferrero, La Donna Delinquente. La Prostituta e la Donna Normale (Rome and Turin: Editori L. Roux \& Cie, 1893).

17. "Police Regulation of Prostitution," British Medical Journal (March $4^{\text {th }}, 1865$ ), 224-225. It is important to note that the policing of prostitutes' bodies was meant, first of all, to protect the police and the army themselves, not the general population: this measure was taken after outbreaks of venereal diseases in garrison cities of the British military forces.

18. Julia A. Laite, “Taking Nellie Johnson's Fingerprints: Prostitutes and Legal Identity in Early Twentieth-Century London," History Workshop Journal 56 (Spring, 2008): 104.

19. Jean-Lucien Sanchez, "L'anthropométrie au service de l'identification des récidivistes: L'exemple de la relégation en Guyane française," Criminocorpus [online], "Identification, contrôle et surveillance des personnes," May $12^{\text {th }}, 2011$. https://journals.openedition.org/criminocorpus/ $365<$ accessed on August 20 $0^{\text {th }}, 2019>$.

20. C. Ainsworth Mitchell, "Science and the Investigation of Crime," Journal of the Royal Society of Arts 69(3570), (April 22nd, 1921): 353-394.

21. Mitchell, "Science and the Investigation of Crime," 353.

22. Mitchell, "Science and the Investigation of Crime," 354.

23. Harold Cummins, "Attempts to Alter and Obliterate Finger-Prints," Journal of Criminal Law and Criminology (1931-1951), 25(6), (March-April, 1935): 982-991.

24. Julie K. Petersen, Understanding Surveillance Technologies. Spy Devices, Privacy, History \& Applications, Revised and Expanded Second Edition (Boca Raton and New York: Auerbach Publications, 2007), 31.

25. Jacques W. Maliniak, "The Plastic Surgeon and Crime," Journal of Criminal Law and Criminology (1931-1951) 26(4), (November, 1935): 594-600.

26. Maliniak, "The Plastic Surgeon and Crime," 599-600.

27. Carlos Clarens, "Hooverville West: The Hollywood G-Man, 1934-1945," Film Comment 13(3), (May-June 1977): 11-12.

28. Clarens, "Hooverville West," 16.

29. Clarens, "Hooverville West," id.

30. Xin Liu, Shinguang Shan, and Xilin Chen, "Face Recognition after Plastic Surgery: A Comprehensive Study," in Computer Vision - ACCV 2012, Lecture Notes in Computer Science 7725, eds. Lee K.M., Matsushita Y., Rehg J.M., Hu Z, Berlin and Heidelberg: Springer (2013): 565-576; Tanupreet Sabharwal and Rashmi Gupta, "Human Identification after Plastic Surgery Using Region Based Score Level Fusion of Local Facial Features," Journal of Information Security and Applications 48 (October, 2019): art. No. 102373. 
31. Jing-cai Liu, Wearable Face Projector, 2017 [online] http://jingcailiu.com/wearable-faceprojector/ <accessed on June $29^{\text {th }}, 2020>$.

\section{ABSTRACTS}

In this paper, I argue that the figures of invisibility in cinema (vanishing characters, blurred or fleeting figures) invent or reinvestigate historic modes of resistance to surveillance and identification techniques. The art of being unseen appears in many early films, in which characters fool the scrutinizing gaze of policemen. I argue that early cinema plays a key role in the depiction of the powers and limitations of surveillance. Indeed, whereas cinema has been largely celebrated through the triumph of vision, this paper provides counterpoints to this theory by identifying, comparing and classifying the limits of identification that have been (re)invented through the history of film.

\section{INDEX}

Keywords: camouflage, falsification, identification, imperceptibility, surveillance

\section{AUTHOR}

\section{RÉMI LAUVIN}

Rémi Lauvin is a PhD student, teaching and research assistant at the Université de Paris. At the crossroads of visual culture and cinema and media studies, his work focuses on camouflage of the filmic body in surveillance cinema and the visual arts. Under the supervision of Emmanuelle André, his dissertation details the forms of resistance to surveillance and identification devices, and aims at characterizing the singularity of the filmic image in the spectacle of disappearing acts. 